\title{
A comparative scanning electron microscopy evaluation of smear layer removal with apple vinegar and sodium hypochlorite associated with EDTA
}

\author{
George Táccio de Miranda CANDEIRO'1, Isabela Barbosa de MATOS ${ }^{2}$, Clarice Fernandes Eloy da COSTA ${ }^{3}$, Cristiane $^{2}$ \\ Sá Roriz FONTELES ${ }^{4}$, Mônica Sampaio do VALE5
}

1- DDS, MSc, PhD student in Endodontics, Postgraduate Program in Dental Sciences, University of São Paulo, São Paulo, Brazil.
2- DDS, Center of Continued Education, Ceará Dental Academy, Fortaleza, CE, Brazil.
3- DDS, MSc, School of Pharmacy, Dentistry and Nursing, Federal University of Ceará, Fortaleza, CE, Brazil.
4- DDS, MSc, PhD, Post-Doctoral Researcher, Professor, Postgraduate Program in Dentistry, School of Pharmacy, Dentistry and Nursing, Federal University
of Ceará, Fortaleza, CE, Brazil.
5- DDS, MSc, PhD, Professor, Postgraduate Program in Dentistry, School of Pharmacy, Dentistry and Nursing, Federal University of Ceará, Fortaleza, CE, Brazil.

Corresponding address: Profa. Dra. Mônica Sampaio do Vale - Universidade Federal do Ceará, Faculdade de Farmácia, Odontologia e Enfermagem Departamento de Clínica Odontológica - Rua Capitão Francisco Pedro, 1210 - Rodolfo Teófilo - Fortaleza - CE - Brasil - 60.430-370 - Phone: +55-85-33668425 - e-mail: monicavale@uol.com.br

Received: November 18, 2009 - Modification: May 02, 2010 - Accepted: October 26, 2010

\section{ABSTRACT}

$\mathrm{O}$ bjective: The purpose of this study was to evaluate by scanning electron microscopy (SEM) the removal of smear layer from the middle and apical root thirds after use of different irrigating solutions. Material and Methods: Forty roots of permanent human teeth had their canals instrumented and were randomly assigned to 4 groups $(n=10)$, according to the irrigating solution: apple vinegar (group A), apple vinegar finished with $17 \%$ ethylenediaminetetraacetic acid (EDTA) (group B), 1\% sodium hypochlorite $(\mathrm{NaOCl})$ finished with 17\% EDTA (group C) and saline (group D - control). After chemomechanical preparation, the roots were cleaved longitudinally and their middle and apical thirds were examined by SEM at $\times 1,000$ magnification. Two calibrated examiners (kappa $=0.92$ ) analyzed the SEM micrographs qualitatively attributing scores that indicated the efficacy of the solutions in removing the smear layer from the surface of the dentin tubules (1 - poor, 2 - good and 3 - excellent). Data from the control and experimental groups were analyzed by the Kruskal-Wallis and Dunn's test, while the Wilcoxon test was used to compare the middle and apical thirds of the canals within the same group $(\alpha=0.05)$. Results: The middle third presented less amount of smear layer than the apical third, regardless of the irrigant. There was statistically significant difference $(p=0.0402)$ among the groups in the middle third. In the apical third, the apple vinegar/EDTA group showed the greatest removal of smear layer $(p=0.0373)$. Conclusion: Apple vinegar associated or not with EDTA was effective in removing smear layer when used as an endodontic irrigant.

Key words: EDTA. Smear layer. Scanning electron microscopy.

\section{INTRODUCTION}

Sodium hypochlorite $(\mathrm{NaOCl})$ is one of the most widely used endodontic irrigants for the chemomechanical preparation of root canals because of its excellent antimicrobial action and capacity of dissolving organic materials ${ }^{15}$, which increase directly with the increase of the concentration ${ }^{21}$. However, the optimal organic tissue-dissolving property of $\mathrm{NaOCl}$ is non-selective, which means that, especially at high concentrations, this chemical agent may dissolve both vital and necrotic pulp remnants indistinguishably and have high toxicity to the periapical tissues in case of inadvertent extrusion through the apical foramen to the periradicular space ${ }^{13}$. Another disadvantage of $\mathrm{NaOCl}$ is that it decreases the mechanical resistance of dentin ${ }^{15,22}$ by causing deterioration of 
collagen and proteoglycans ${ }^{14}$. There are also reports of accidents and allergic reactions to the use of $\mathrm{NaOCl}$ during root canal therapy $3,17,18,29$. Therefore, research has been done to find an irrigating solution that may have better biocompatibility than $\mathrm{NaOCl}$ while maintaining its properties of tissue solving capacity and high bactericidal action.

The use of different chemical irrigants for smear layer removal during the root canal treatment has been proposed, such as EDTA ${ }^{23,28}$, citric acid ${ }^{23}$, maleic acid $^{19}$ and apple vinegar ${ }^{9,24,30 .}$

Vinegar has been indicated as an antiseptic agent due to its medicinal properties and has been used for the treatment of infected wounds ${ }^{26}$. Distilled white vinegar and wine vinegar are composed mainly of acetic acid, whereas apple vinegar is composed mainly of malic acid, which has therapeutic properties ${ }^{2}$. More recently, the use of apple vinegar as an auxiliary solution in the chemomechanical preparation of root canals has also been investigated and deserves attention due to the promising results obtained when compared to traditional endodontic irrigants, such as $\mathrm{NaOCl}$ and EDTA $^{4}$. Pioneering studies evaluating the efficacy of apple vinegar on the endodontic microbiota, its physicochemical properties and its role on the periapical tissue healing have been done $e^{8,9,10,30}$. It has good cost-effectiveness and its principle of action in mineralized tissue is similar to that of EDTA ${ }^{4}$. Apple vinegar associates a good capacity to remove smear layer from the dentinal tubule entrances ${ }^{8,9,30}$ with bactericidal action against microorganisms that are frequently associated with endodontic infections, such as Staphylococcus aureus ${ }^{7}$ and Enterococcus faecalis ${ }^{10}$. The high biocompatibility of apple vinegar is mainly attributed to the high concentration of malic acid in its composition ${ }^{2}$.

The purpose of this study was to evaluate by scanning electron microscopy (SEM) the removal of smear layer from the middle and apical thirds of root canals irrigated with $1 \% \mathrm{NaOCl}$ and apple vinegar associated or not with EDTA.

\section{MATERIAL AND METHODS}

Forty extracted human maxillary and mandibular molars were selected from a random collection and were checked for absence of root caries, cracks and structural defects. Soft debris were eliminated with hand curettes. Crowns were removed at the cementoenamel junction with a carborundum disc under distilled water cooling, and the palatal roots of the maxillary molars and distal roots of mandibular molars were trimmed coronally to a uniform length of $16 \mathrm{~mm}$ and stored in saline until use to prevent dehydration.

The working length was checked with a \#10 K-file (Dentsply/Maillefer, Ballaigues, Switzerland) introduced into the root canal of each tooth up to the point when it was visualized at the apex and then pulled back $1 \mathrm{~mm}$. All canals were instrumented up to a \#45 K-file (Dentsply/Maillefer, Ballaigues, Switzerland). The roots were randomly assigned into 4 groups in each 10 specimens, each according to the irrigating solution used during chemomechanical preparation: A- Apple vinegar (Minhoto, Grupo Raymundo da Fonte, Paulista, PE, Brazil); B- Apple vinegar (Minhoto) and 17\% EDTA as a final rinse (Biodinâmica Química e Farmacêutica Ltda., Ibiporã, PR, Brazil); C- 1\% $\mathrm{NaOCl}$ (Biodinâmica Química e Farmacêutica Ltda.) and $17 \%$ EDTA as a final rinse; D- Saline (control group). The canals were irrigated with $2 \mathrm{~mL}$ of each solution at every change of file followed by fluid content aspiration.

After chemomechanical preparation, grooves were prepared along the long axis of the roots with a water-cooled diamond disk (KG Sorensen Ind. Com., São Paulo, SP, Brazil) and a surgical chisel was used to cleave the roots longitudinally in a buccolingual direction to expose the entire canal extension. The middle and apical thirds of the canals were examined with a scanning electron microscope (JSM-T220A; JEOL, Tokyo, Japan) at $\times 1,000$ magnification. Two calibrated examiners (kappa=0.92) examined the SEM micrographs qualitatively attributing scores that indicated the efficacy of the solutions in removing the smear layer from the dentinal walls surface and from dentin tubules entrance, according to Vale, et al. ${ }^{28}$ (2003): Score 3 (Excellent) - no smear layer, total extension of dentin with open dentin tubules (Figure 1); Score 2 (Good): few areas covered by smear layer, and several dentin tubules visible (Figure 2); and Score 1 (Poor): all areas covered by smear layer, and no dentin tubules visible (Figure 3 ).

Data from the control and experimental groups were analyzed by the Kruskal-Wallis and Dunn's test, while the Wilcoxon test was used to compare the middle and apical thirds of the canals within the same group. A significance level of $5 \%$ was set for all analyses.

\section{RESULTS}

A significantly large number of specimens in the groups irrigated with apple vinegar ( $A$ and $B$ ) showed greater removal of smear layer from the middle third compared to the apical third $(p<0.05)$, while no statistically significant difference ( $p>0.05$ ) was found between the middle and apical thirds in the $C$ and $D$ groups. The $B$ group (apple vinegar plus EDTA) showed the greatest efficacy in removing the smear layer from both the middle and apical thirds, but this difference was significant only in relation to groups C and D. (Figures 4 and 5$)(p<0.05)$. 


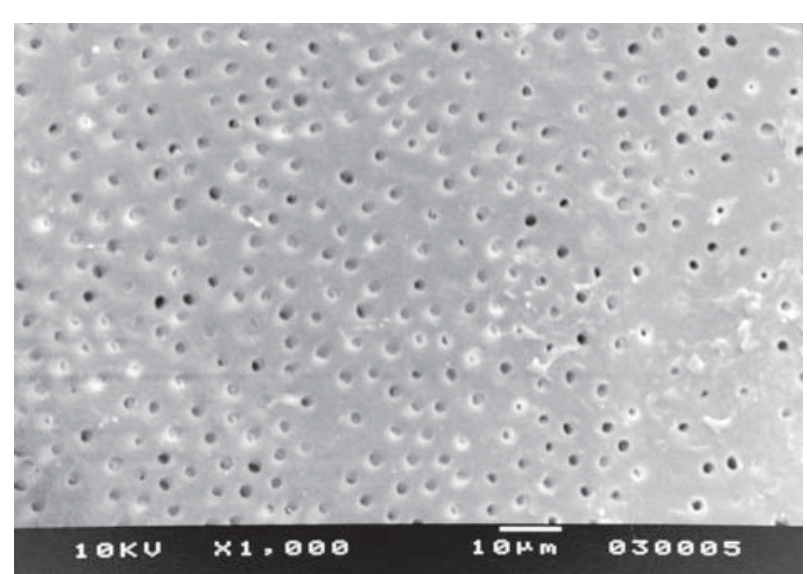

Figure 1- Scanning electron microscopy (SEM) micrograph of root dentin surface showing absence of smear layer and fully exposed dentin tubules, corresponding to score 3 (Excellent) $(\times 1,000$ magnification $)$

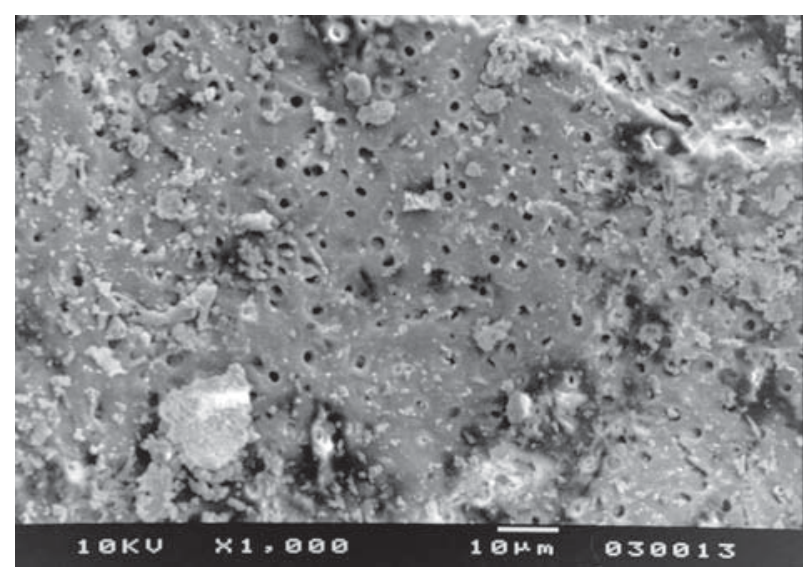

Figure 2-Scanning electron microscopy (SEM) micrograph of root dentin surface showing partial closure of the dentin tubules entrances by smear layer, corresponding to score 2 (Good) (×1,000 magnification)

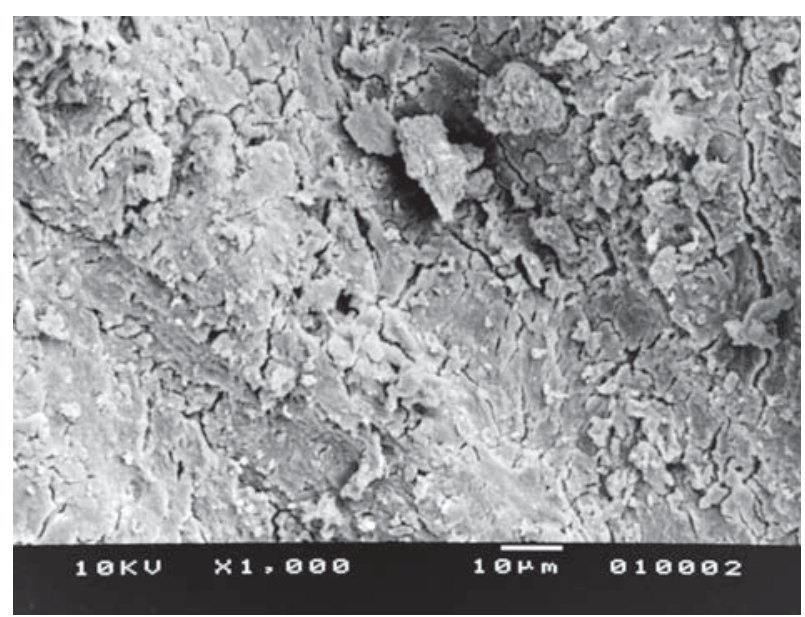

Figure 3- Scanning electron microscopy (SEM) micrograph of root dentin surface showing total closure of the dentinal tubule entrances by smear layer, corresponding to score 1 (Poor) (×1,000 magnification)

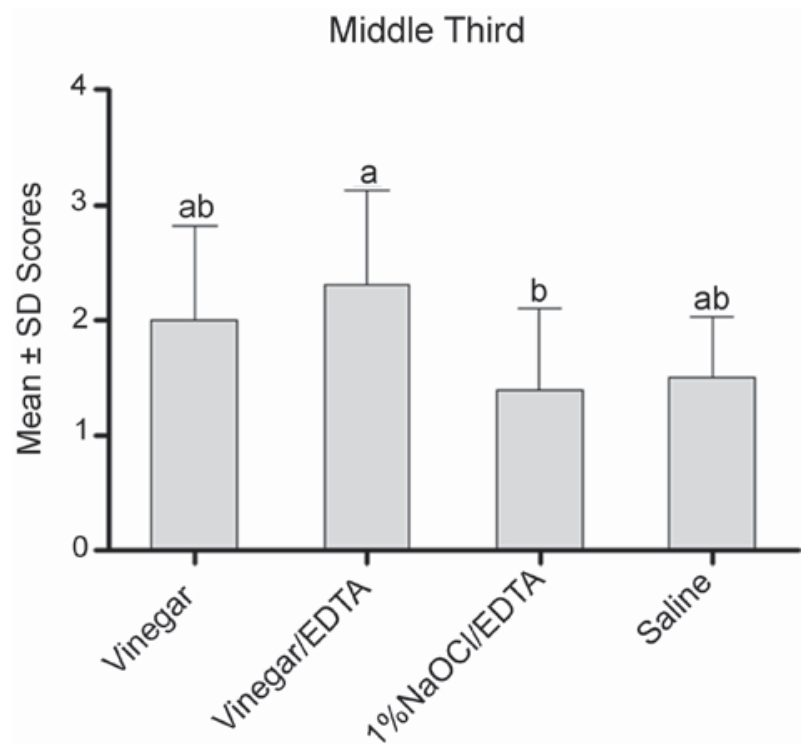

Figure 4- Mean scores \pm Standard deviation recorded for each group $(n=10)$ in the middle root third. The groups with a different superscript letter are statistically different $(p<0.05)$

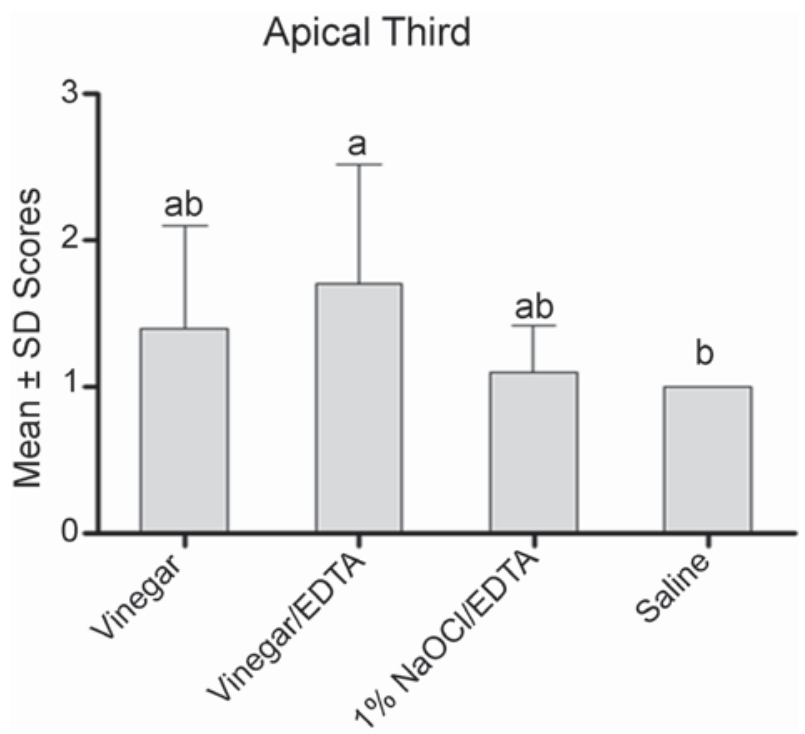

Figure 5- Mean scores \pm Standard deviation recorded for each group $(n=10)$ in the apical root third. The groups with a different superscript letter are statistically different $(p<0.05)$

The B group produced significantly cleaner canals in both middle and apical thirds $(p=0.0402$ and $p=0.0373$, respectively). The sequence of the irrigating solutions in a decreasing order of efficacy in smear layer removal was as follows: B-apple vinegar/EDTA $>$ A-apple vinegar $>$ D-saline $>\mathrm{C}-\mathrm{NaOCl} /$ EDTA, representing the middle third (Figure 4) and $\mathrm{B}$-apple vinegar/EDTA $>$ A-apple vinegar $>\mathrm{C}-\mathrm{NaOCl} /$ EDTA $>$ D-saline, representing the apical third (Figure 5). 


\section{DISCUSSION}

The main goals of the chemomechanical preparation are to eliminate bacteria and their byproducts from the root canal system, remove pulp tissue remnants and contaminated organic and inorganic debris that are formed during instrumentation and compacted into the dentin tubules and produce a continuously tapered shape in the crown-apex direction to allow effective irrigation and three-dimensional obturation of the canal space. Chemical endodontic irrigants must have some important properties such as biocompatibility, dissolution of organic tissues, bactericidal action and capacity to remove smear layer from the canal walls. Different solutions, such as $\mathrm{NaOCl}$ at several concentrations, chlorhexidine and more recently apple vinegar, have been used as endodontic irrigants.

The biocompatibility of apple vinegar is attributed to the presence in its composition of malic acid ${ }^{2}$, which has therapeutic properties. It increases the organism resistance because it is one of the acids of the Krebs cycle, which is a set of reactions responsible for production of energy in the cells. In addition, apple vinegar has a remarkable medicinal potential due to its high mineral content (potassium, phosphorus, magnesium, sulfur, calcium, fluoride and silicon $)^{8}$, and contains other elements, such as pectin, beta-carotene, enzymes and amino acids, which attack free radicals that affect the immune system ${ }^{8,10}$, and may have some beneficial role the periapical repair process. Therefore, it may be assumed that apple vinegar has some antiinflammatory activity, which is an important characteristic for an endodontic irrigating solution. In addition to the biocompatibility, it has been demonstrated that apple vinegar has bactericidal activity against $E$. faecalis ${ }^{10}$, which is one of the main microorganisms associated with endodontic treatment failure.

The $1 \% \mathrm{NaOCl}$ solution has considerable antibacterial activity and tissue-dissolving property $1,6,16,20,21$, and do not cause significant decrease of the structural resistance of dentin ${ }^{4}$.

In line with the findings of previous investigations ${ }^{25,27}$, in the present study, the apical third was more challenging for smear layer removal compared to the middle third. This can be explained by the fact that the access of instruments and chemical solutions to the middle third is easier and the exposed dentin tubules orifices are larger.

Failure to remove smear layer from the root canal walls is considered as one of the main reasons of endodontic therapy failure ${ }^{5,11,12}$. Removal of the smear layer can allow intracanal medicaments to penetrate the dentin tubules in infected root canals more readily and consequently cause a better disinfection procedure ${ }^{11}$. The lack of adherence between the filling material and the smear-covered canal walls compromise the apical seal, which may result in apical leakage, favoring the survival and multiplication of bacteria that were not eliminated during the chemomechanical preparation ${ }^{5,11,12,20}$.

In a recent SEM evaluation, Spanó, et al. ${ }^{24}$ (2009) verified smear layer removal with several root canal chelators (15\% EDTA, 10\% citric acid, $10 \%$ sodium citrate, apple vinegar, $5 \%$ acetic acid, $5 \%$ malic acid, and $1 \% \mathrm{NaOCl}$ ) and found that EDTA and citric acid were the most efficient solutions. However, those authors did not use apple vinegar as an irrigating solution but rather as a chelating agent for 5 min after chemomechanical preparation with $1 \% \mathrm{NaOCl}$, which makes it difficult to establish a comparison with the findings of the present study.

In the middle third, the groups irrigated with apple vinegar, especially when associated with EDTA, showed greater efficacy than $\mathrm{NaOCl}$ in smear layer removal, which is in agreement with the results of Prabhu, et al. ${ }^{19}$ (2003). In the apical third, the association of apple vinegar and EDTA was more effective than the use of $\mathrm{NaOCl}$ associated with EDTA, in the same way as reported by Estrela, et al. ${ }^{9}$ (2007) and Zandim, et al. ${ }^{30}$ (2004). Since malic acid is present in the composition of apple vinegar, the results of the present study are consistent with those of Prabhu, et al. ${ }^{19}$ (2003), who investigated the smear layer removal capacity of malic acid and found significantly better results than EDTA associated with $5.25 \% \mathrm{NaOCl}$.

Hence, the choice for the irrigating solutions used during endodontic therapy must take into account some important properties such as biocompatibility, bactericidal action and efficacy in eliminating organic and inorganic debris from the canal walls in order to promote greater elimination of microorganisms from the root canal system and improve the seal between the filling materials and the dentin walls.

\section{CONCLUSIONS}

It may be concluded that the apple vinegar associated or not with EDTA was more effective in removing smear layer from the root canals than $\mathrm{NaOCl}$ associated with EDTA. Clinical investigations are needed to corroborate the use of apple vinegar in endodontics, since it is a biocompatible substance and which produces an effective elimination of smear layer in vitro, being potentially considered as an alternative for root canal cleaning. 


\section{REFERENCES}

1- Baumgartner JC, Cuenin PR. Efficacy of several concentrations of sodium hypochlorite for root canal irrigation. J Endod. 1992;18:605-12.

2- Caligiani A, Acquotti D, Palla G, Bocchi V. Identification and quantification of the main organic components of vinegars by high resolution 1H NMR spectroscopy. Anal Chim Act. 2007;585:110-9. 3- Çalişkan MK, Türkün M, Alper S. Allergy to sodium hypochlorite during root canal therapy: a case report. Int Endod J. $1994 ; 27: 163-7$.

4- Costa D, Dalmina F, Irala LED. The use of the vinegar as a chemical auxiliary in endodontics: a literature review. Rev Sul-Bras Odontol. 2009;6:185-93.

5- De-Deus G, Gurgel-Filho ED, Ferreira CM, Coutinho-Filho T. Intratubular penetration of root canal sealers. Pesqui Odontol Bras. 2002;16:332-6.

6- Dunavant TR, Regan JD, Glickman GN, Solomon ES, Honeyman AL. Comparative evaluation of endodontic irrigants against Enterococcus faecalis biofilms. J Endod. 2006;32,527-31.

7- Estrela C, Estrela CRA, Decurcio DA, Silva JA, Bammann LL. Antimicrobial potential of ozone in an ultrasonic cleaning system against Staphylococcus aureus. Braz Dent J. 2006;17:134-8.

8- Estrela C, Holland R, Bernabé PFE, Souza V, Estrela CRA. Antimicrobial potential of medicaments used in healing process in dogs' teeth with apical periodontitis. Braz Dent J. 2004;15:181-5. 9- Estrela C, Lopes HP, Elias CN, Leles CR, Pécora JD. Cleanliness of the surface of the root canal of apple vinegar, sodium hypochlorite, chlorhexidine and EDTA. Rev Assoc Paul Cir Dent. 2007;61:177-82. 10- Estrela CR, Estrela C, Cruz Filho AM, Pécora JD. ESP substance: option in endodontic therapy. J Bras Endod. 2005;5:273-9.

11- Farhad A, Elahi T. The effect of smear layer on apical seal of endodontically treated teeth. J Res Med Sci. 2004;9:130-3.

12- Kennedy WA, Walker WA, Gough RW. Smear layer removal effects on apical leakage. J Endod. 1986;12:21-7.

13- Kuruvilla JR, Kamath MP. Antimicrobial activity of $2.5 \%$ sodium hypochlorite and $0.2 \%$ chlorhexidine gluconate separately and combined as irrigants. J Endod. 1998;24:472-6.

14- Lee BS, Hsieh TT, Chi DC, Lan WH, Lin CP. The role of organic tissue on the punch shear strength of human dentin. J Dent. 2004;32:101-7.

15- Marending M, Paqué F, Fisher J, Zehnder M. Impact of irrigant sequence mechanical properties of human root dentin. J Endod. 2007;33:1325-8.

16- Naenni N, Thoma K, Zehnder M. Soft tissue dissolution capacity of currently used and potential endodontic irrigants. J Endod. 2004;30:785-7.
17- Pelka M, Petschelt A. Permanent mimic musculature and nerve damage caused by sodium hypochlorite: a case report. Oral Surg Oral Med Oral Pathol Oral Radiol Endod. 2008;106:80-3.

18- Pontes F, Pontes H, Adachi P, Rodini C, Almeida D, Pinto D Jr. Gingival and bone necrosis caused by accidental sodium hypochlorite injection instead of anaesthetic solution. Int Endod J. $2008 ; 41: 267-70$.

19- Prabhu SG, Rahim N, Bhat KS, Mathew J. Comparison of removal of endodontic smear layer using $\mathrm{NaOCl}$, EDTA, and different concentrations of maleic acid - a SEM study. Endodontology. 2003;15:20-5.

20- Saleh IM, Ruyter IE, Haapasalo M, Ørstavik D. Bacterial penetration along different root canal filling materials in the presence or absence of smear layer. Int Endod J. 2008;41:32-40. 21- Sirtes G, Waltimo T, Schaetzle M, Zehnder M. The effects of temperature on sodium hypochlorite short-term stability, pulp dissolution capacity, and antimicrobial efficacy. J Endod. 2005;31:669-671.

22- Soares JC, Santana FR, Silva NR, Pereira JC, Pereira CA. Influence of the endodontic treatment on mechanical properties of root dentin. J Endod. 2007;33:603-6.

23- Sousa SMG, Silva TL. Demineralization effect of EDTA, EGTA, CDTA and citric acid on root dentin: a comparative study. Braz Oral Res. 2005; 19:188-92.

24- Spanó JCE, Silva RG, Guedes DFC, Sousa-Neto MD, Estrela C, Pécora JD. Atomic absorption spectrometry and scanning electron microscopy evaluation of concentration of calcium ions and smear layer removal with root canal chelators. J Endod. 2009;35:727-30. 25- Teixeira CS, Felippe MCS, Felippe WT. The effect of application time of EDTA and $\mathrm{NaOCl}$ on intracanal smear layer removal: an SEM analysis. Int Endod J. 2005;38:285-90.

26- Thacker E. The vinegar book. São Paulo: Pacific Post Com. Ltda.; 2000.

27- Torabinejad M, Cho Y, Khademi AA, Bakland LK, Shabahang $S$. The effect of various concentrations of sodium hypochlorite on the ability of MTAD to remove the smear layer. J Endod. 2003;29:233-9.

28- Vale MS, Pinto SAH, Ferreira FBA, Melo ES. Comparative study of the degree of cleanliness of root canals with two formulations of EDTA. Rev Assoc Paul Cirurg Dent. 2003;57:118-22.

29- Witton R, Henthorn K, Ethunandan M, Harmer S, Brennan PA. Neurological complications following extrusion of sodium hypochlorite solution during root canal treatment. Int Endod J. 2005;38,843-8.

30- Zandim DL, Corrêa FOB, Sampaio JEC, Rossa Júnior C. The influence of vinegars on exposure of dentinal tubules: a SEM evaluation. Braz Oral Res. 2004;18:63-8. 